\title{
Children of those treated surgically for Hirschsprung's disease
}

\author{
C O CARTER, KATHLEEN EVANS, AND VERONICA HICKMAN \\ From the MRC Clinical Genetics Unit, Institute of Child Health, London WC1N 1EH
}

SUMMARY The risk of recurrence of Hirschsprung's disease in sibs is reasonably well established. Survivors of early successful operations (rectosigmoidectomy) are now reaching adult life and are asking about risks to their children. The authors report a preliminary study on which to base a risk estimate.

Studies on sibs show that for short segment index patients the risk to brothers is about 1 in 20 and for sisters about 1 in 100 . For long segment index patients the risk is about 1 in 10 irrespective of sex. In the present study it was found that one son in 52 was possibly affected, and one daughter in 47 was certainly affected, of short segment index patients. Of long segment index patients one son in three was probably affected, and the one daughter was certainly affected.

One long segment patient had a child with a short segment affected and one short segment patient had a child with a long segment affected. This confirms the impression, given by single case reports of parent and child affected, that there is less likelihood of concordance in length of aganglionic segment in parent and child than in sibs.

For the present it is appropriate to give an estimated risk of about $2 \%$ for offspring of short segment index patients, but a relatively higher risk for offspring of long segment index patients.

Substantial information is available on the risk to sibs of index patients with Hirschsprung's disease..$^{1-4}$ In the largest series, ${ }^{3}$ based on 207 index patients, 18 of 381 sibs were affected. The proportion of sibs affected was higher when the index patient had a 'long' aganglionic segment (that is, extending beyond the pelvic colon) and also when the index patient was female. Affected sibs were in most instances concordant for whether the segment was 'long' or 'short'. The findings in the family studies of Althoff ${ }^{2}$ and Passarge ${ }^{4}$ are similar. The very long segment cases involving large and small bowel up to the duodenojejunal junction are probably separate, and here inheritance may be simply recessive. ${ }^{5}$

Survivors of the operation for Hirschsprung's disease, introduced in 1948, are now young adults and are asking about risks to their children. The proportion of parents of index patients affected is no guide to the risk to children since, until 1948, few such patients would have survived to reproduce. There are, however, a number of individual case reports of affected children born to parents who were histologically proved to be affected in adult life and Received for publication 11 April 1980 details are given in table 1 . In addition Rosin et al ${ }^{11}$ reported three normal children born to a male patient and Swenson ${ }^{12}$ reported that eight male patients had had children, but without further detail.

This paper is the first report of the children born to a consecutive series of surviving patients treated operatively at The Hospital for Sick Children, London.

\section{Material and methods}

We set out to follow up the 207 index patients of the

TABLE 1 Case reports of parent and child both with Hirschsprung's disease

\begin{tabular}{|c|c|c|}
\hline Report & Parent & Child \\
\hline $\begin{array}{l}\text { Bodian and Carter }{ }^{3} \\
\text { Donald and Donald } 6 \\
\text { Madsen } 7 \\
\text { Emanuel et al } 8 \\
\text { Bowring } 9 \\
\text { Ehrenpreis } 10\end{array}$ & $\begin{array}{l}\text { Mother (S) } \\
\text { Mother (S) } \\
\text { Mother (Ns) } \\
\text { Mother (S) } \\
\text { Mother (S) } \\
\text { Mother (S) }\end{array}$ & $\begin{array}{l}\text { Daughter (S) } \\
\text { Son (L) } \\
\text { Son (Ns); son (Ns) } \\
\text { Son (S) } \\
\text { Son (L); son (L) } \\
\text { Son (S) }\end{array}$ \\
\hline
\end{tabular}


original series of Bodian and Carter, ${ }^{3}$ all treated operatively before 1959 , to see how often their children also had Hirschsprung's disease.

We knew at the outset that 38 of the index patients were dead (two of these had Down's syndrome) and their families were not included in the study. In addition, a further six patients were not included because they were known to be severely handicapped and it was thought unlikely that they had married. The handicaps were: occipital encephalocele (No 54); cataract and deafness (No 69); Down's syndrome (No 96); cleft palate and mental retardation (No 136); deafness and mental retardation following meningitis (No 142); left spastic hemiplegia, partial blindness, and severe mental retardation (No 155). Of the remaining index patients, six were abroad and their addresses were not known, and 21 (including one adopted) were not able to be traced through the National Health Service Central Register. The remaining 136 families supplied information, which was obtained at a home visit and later brought up to date by letter.

None of these index patients had Waardenburg's syndrome.

\section{Results}

\section{OFFSPRING}

Of the 136 index patients seen, 58 had had 103 children. Of the male index patients, 46 had had 43 sons (one probably affected) and 41 daughters. Of the female index patients, 12 had had 12 sons (one possibly affected) and seven daughters (two certainly affected). The details using the serial numbers for families from the original paper $^{3}$ are shown in the appendix, where patients are distinguished by the length of segment, date of birth, and details of the children who have been born to them.

Table 2 shows the numbers of male and female patients separated into long and short segment groups and the numbers of children, distinguishing those affected, born to them.

One female index patient (No 150), who herself had a long segment lesion, had a daughter who had short segment Hirschsprung's disease. The child was described as having ultra-short segment disease and this was confirmed by histological examination of a rectal biopsy specimen. One male index patient with a long segment (No 38), who had a first cousin affected, had a son who died at 5 months who was probably affected. The child was constipated from birth and died with acute enterocolitis. There was no necropsy. Acute and fatal enterocolitis is a feature of Hirschsprung's disease and may occur even after successful operation. One female index patient (No 113), who had short segment disease, had a daughter with long segment disease, confirmed histologically, with the aganglionic segment extending into the transverse colon.

In addition to these two certainly and one probably affected offspring, a woman patient (No 16), who had short segment disease, had a son who died suddenly at 16 months. This child had acute enterocolitis and the necropsy noted internal haemorrhage and shock resulting from multiple superficial erosions of the gastric and duodenal mucosa. No sections of large intestine were examined. This child may also have had Hirschsprung's disease.

No other malformations were observed in offspring, apart from a persistent ductus arteriosus in a child of patient No 12. A son of male index patient No 129 was stillborn because of placental insufficiency.

Thus, of 103 children, two are certainly affected, one is probably affected, and one is possibly affected. It is noteworthy that of only four children born to patients with long segments one was certainly and one probably affected.

TABLE 2 Offspring of index patients (those affected shown in brackets)

\begin{tabular}{|c|c|c|c|c|c|c|c|c|c|}
\hline & \multicolumn{4}{|c|}{ Male index patients } & \multicolumn{4}{|c|}{ Female index patients } & \multirow{2}{*}{$\begin{array}{l}\text { Total } \\
\text { children }\end{array}$} \\
\hline & $\begin{array}{l}\text { Total } \\
\text { visited }\end{array}$ & $\begin{array}{l}\text { With } \\
\text { children }\end{array}$ & Sons & Daughters & $\begin{array}{l}\text { Total } \\
\text { visited }\end{array}$ & $\begin{array}{l}\text { With } \\
\text { children }\end{array}$ & Sons & Daughters & \\
\hline \multirow{2}{*}{$\begin{array}{l}\text { Short } \\
\text { segment } \\
\text { Long } \\
\text { segment }\end{array}$} & 102 & 45 & 41 & 41 & 20 & 10 & $11(P)$ & \multirow{2}{*}{$\begin{array}{l}6(L) \\
\text { No } 113 \\
1(S) \\
\text { No } 150 \\
7\end{array}$} & 99(L) \\
\hline & 10 & 1 & $\begin{array}{l}\text { 2(A) } \\
\text { No } 38\end{array}$ & 0 & 4 & 2 & & & $\begin{array}{c}\text { 4(A) } \\
\text { (S) }\end{array}$ \\
\hline
\end{tabular}

(S) $=$ short segment

(L) $=$ long segment

(A) $=$ probably affected, length of segment not known

(P) $=$ possibly affected 
TABLE 3 Proportion of sibs of index patients with Hirschsprung's disease also affected (Bodian and Carter $^{3}$ )

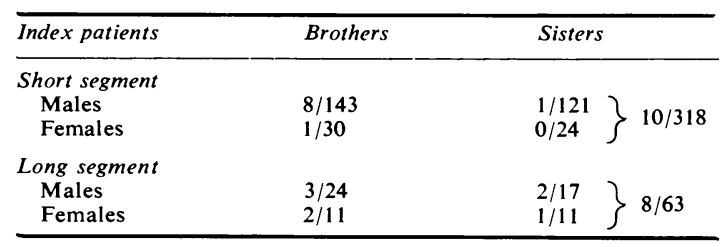

\section{NEPHEWS AND NIECES}

No systematic attempt was made to collect further information on nephews and nieces, but since the original report ${ }^{3}$ a sister of a short segment male index patient (No 158) has had a daughter with a short segment affected.

\section{Discussion}

With congenital malformations the usual finding is that the proportion affected of children of index patients is similar to that of sibs affected. ${ }^{13}$

The proportion of sibs affected in the Bodian and Carter series ${ }^{3}$ is shown in table 3 .

In all instances the affected sibs were concordant with the index patient for being 'long' or 'short' segment. This is the general rule though exceptions have been reported, for example, families II and IV of Emanuel et al. 8

Passarge, ${ }^{4}$ with a somewhat different definition of short and long segment, found four of 144 sibs affected and two of these (long segments) were among the sibs of the only six long segment index patients; however, the total number of sibs of short and long segment patients is not stated.

At a rough approximation this would suggest an estimated $3 \%$ risk to sibs of short segment cases and a $12 \%$ risk to sibs of long segment cases, and that for short segment cases there is a higher risk for brothers, about $5 \%$, than for sisters, less than $1 \%$. For long segment cases there is little difference for brothers and sisters.

The findings so far in our series of children, 1/52 sons possibly affected and 1/47 daughters certainly affected of short segment cases, and $1 / 3$ sons probably affected and 1/1 daughters certainly affected of long segment cases, are compatible with the proportion affected in sibs, though the series is too small for reliable comparison. However, the series fully confirms the impression given by previous single reports, recorded in table 1 , that there is less likelihood of concordance for the length of aganglionic segment in parent and child than in sibs. We have a long segment parent (No 150) with a short segment child and a short segment parent (No 113) with a long segment child.

In the original report ${ }^{3}$ such discordance between index patient and affected relation was noted for nephews and nieces.

As regards genetic counselling, it is appropriate at present to give a risk estimate of about $2 \%$ for the children of short segment patients, a high risk for the children of long segment patients, and to bear in mind that the length of segment affected may differ in parent and child.

\section{References}

1 Bodian M, Carter CO, Ward BCH. Hirschsprung's Disease. Lancet 1951 ; i:302-9.

2 Althoff W. Zur Genetik der Hirschsprungsehen Krankheit. Z Menschl Vererb Konstitutionsl 1962;36:314-40.

3 Bodian M, Carter CO. A family study of Hirschsprung's disease. Ann Hum Genet 1963;26:261-77.

4 Passarge E. The genetics of Hirschsprung's disease. N Engl J Med 1967;276:138-43.

5 McKinnon AE. Total intestinal agangliosis. An autosomal recessive condition. Arch Dis Child 1977;52:898-9.

6 Donald JG, Donald JW. Aganglionic disease in the newborn. Surgery 1964;56:644-50.

7 Madsen CM. Hirschsprung's disease. Copenhagen: Munksgaard, 1964.

8 Emanuel B, Padorr MP, Swenson O. Familial absence of myenteric plexus (congenital megacolon). A study of 6 families. J Pediatr 1965;67:381-6.

9 Bowring AC. Long segment Hirschsprung's disease. Pacific Medicine and Surgery 1966;74:264-6.

10 Ehrenpreis T. Hirschsprung's disease. Chicago: Year Book Medical Publishers, 1970:58-9.

11 Rosin JD, Bargen JA, Waugh JM. Congenital megacolon in a man of 54 years. Proc Mayo Clinic 1950;25:710-3.

12 Swenson O. Follow up on 200 patients treated with Hirschsprung's disease during a 10 year period. Ann Surg 1957;146:706-14.

13 Carter CO. Genetics of common single malformations. BrMed Bull 1976;32:21-6.

Requests for reprints to Professor C O Carter, MRC Clinical Genetics Unit, Institute of Child Health, 30 Guilford Street, London WC1N 1EH.

APPENDIX

\begin{tabular}{|c|c|c|c|c|}
\hline \multirow{2}{*}{$\begin{array}{l}\text { Index patient } \\
\text { Serial No }\end{array}$} & \multirow{2}{*}{$\begin{array}{l}\text { DOB } \\
\text { of index } \\
\text { patient }\end{array}$} & \multicolumn{2}{|c|}{ Children } & \multirow{2}{*}{$\begin{array}{l}\text { Other affected } \\
\text { relative }\end{array}$} \\
\hline & & Sons & Daughters & \\
\hline \multicolumn{5}{|l|}{ MALES } \\
\hline $\begin{array}{r}\text { Long segment } \\
38\end{array}$ & $9 / 49$ & $2^{A}$ & - & $\begin{array}{l}\text { Mother's brother's } \\
\text { daughter L }\end{array}$ \\
\hline $\begin{array}{r}\text { Short segment } \\
5 \\
6 \\
9 \\
11 \\
12 \\
13 \\
14 \\
15 \\
17 \\
18\end{array}$ & $\begin{array}{l}5 / 48 \\
3 / 46 \\
8 / 43 \\
4 / 43 \\
3 / 45 \\
4 / 45 \\
6 / 44 \\
4 / 46 \\
4 / 42 \\
5 / 44\end{array}$ & $\begin{array}{l}1 \\
1 \\
- \\
- \\
2 \\
2 \\
1 \\
- \\
- \\
1\end{array}$ & $\begin{array}{l}1 \\
1 \\
1 \\
2 \\
1 \\
- \\
- \\
2 \\
1 \\
-\end{array}$ & \\
\hline
\end{tabular}


APPENDIX - continued

\begin{tabular}{|c|c|c|c|c|}
\hline \multirow{2}{*}{$\begin{array}{l}\text { Index patient } \\
\text { Serial No }\end{array}$} & \multirow{2}{*}{$\begin{array}{l}\text { DOB } \\
\text { of index } \\
\text { patient }\end{array}$} & \multicolumn{2}{|c|}{ Children } & \multirow{2}{*}{$\begin{array}{l}\text { Other affected } \\
\text { relative }\end{array}$} \\
\hline & & Sons & Daughters & \\
\hline 20 & $3 / 39$ & 2 & - & \multirow{26}{*}{$\begin{array}{l}\text { Brother S } \\
\text { Brother S } \\
\left\{\begin{array}{l}\text { Brother S } 164 \\
\text { Brother S } 165\end{array}\right.\end{array}$} \\
\hline 21 & $3 / 44$ & 1 & 2 & \\
\hline 22 & $5 / 49$ & 1 & 2 & \\
\hline 24 & $5 / 46$ & 1 & - & \\
\hline 26 & $2 / 34$ & 2 & - & \\
\hline 28 & $12 / 45$ & - & 1 & \\
\hline 29 & $1 / 44$ & 1 & 1 & \\
\hline 31 & $6 / 45$ & 2 & 1 & \\
\hline 32 & $10 / 35$ & 1 & 1 & \\
\hline 35 & $9 / 48$ & - & 1 & \\
\hline 36 & $9 / 38$ & 1 & 1 & \\
\hline 37 & $12 / 34$ & 2 & 2 & \\
\hline 39 & $5 / 50$ & $=$ & 1 & \\
\hline 42 & $3 / 52$ & 1 & 1 & \\
\hline 48 & $3 / 46$ & 1 & i & \\
\hline 58 & $12 / 44$ & - & 2 & \\
\hline 61 & $7 / 57$ & - & 1 & \\
\hline 73 & $12 / 46$ & 2 & - & \\
\hline 74 & $10 / 40$ & 1 & 1 & \\
\hline 76 & $4 / 42$ & 1 & 1 & \\
\hline 79 & $1 / 43$ & - & 1 & \\
\hline 83 & $2 / 54$ & - & 1 & \\
\hline 126 & $5 / 41$ & - & 2 & \\
\hline 129 & $11 / 49$ & $\begin{array}{l}1 \mathrm{SB} \\
1\end{array}$ & - & \\
\hline 137 & $12 / 51$ & 1 & - & \\
\hline 139 & $6 / 47$ & 1 & 2 & \\
\hline
\end{tabular}

$L=$ Long segment $\mathbf{S}=$ Short segment

$A=$ Probably affected, length of segment not known $\mathbf{P}=$ Possibly affected

Sister's daughter A

Twin 165S,

Brother 31S

FEMALES

Long segment

$$
\begin{array}{rrrr}
75 & 9 / 51 & 1 & - \\
150 & 8 / 56 & - & 15
\end{array}
$$

Short segment

\begin{tabular}{rrll}
16 & $3 / 48$ & $2^{\mathrm{P}}$ & - \\
19 & $3 / 47$ & - & 1 \\
80 & $5 / 52$ & - & 1 \\
113 & $2 / 58$ & $\overline{1}$ & $1 \mathrm{~L}$ \\
125 & $11 / 49$ & 2 & - \\
127 & $2 / 51$ & 1 & 1 \\
131 & $10 / 47$ & 2 & - \\
141 & $5 / 48$ & 2 & $\overline{1}$ \\
156 & $9 / 50$ & 1 & 1 \\
204 & $2 / 49$ & 1 & 1 \\
\hline
\end{tabular}

$\mathbf{S B}=$ Stillbirth

$\stackrel{8}{2}$

$\stackrel{9}{\square}$

$\overrightarrow{7}$
$\frac{1}{0}$
$\frac{0}{0}$
$\frac{0}{0}$
$\frac{0}{0}$
$\frac{D}{0}$

$\vec{\circ}$

$\overrightarrow{\vec{\omega}}$

W.

ఢ⿳⺈冂大

$\vec{\infty}$

N

$\stackrel{\infty}{\mathrm{d}}$

오

$\vec{\nabla}$

을.

$\vec{\bullet}$

$\infty$

뭉

结

\%

(D

흠

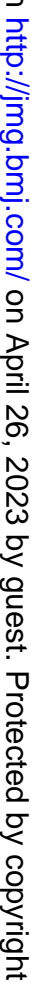

